\title{
Light intensities alter growth and essential oil of patchouli under shade nets
}

\section{Aurislaine Santos Ribeiro' ${ }^{1}$ Suzan Kelly Vilela Bertolucci ${ }^{2}$ (i) Alexandre Alves de Carvalho ${ }^{1}$ (i) Wesley Naves Tostes $^{1}$ Ad Adriane Duarte Coelho ${ }^{1}$ (D) José Eduardo Brasil Pereira Pinto ${ }^{1^{*}}$ (ID}

${ }^{1}$ Laboratório de Cultura de Tecidos Vegetais e Plantas Medicinais, Departamento de Agricultura, Universidade Federal de Lavras (UFLA), 37200-900, Lavras, MG, Brasil. E-mail: jeduardo@ufla.br. "Corresponding author.

${ }^{2}$ Laboratório de Fitoquímica e Plantas Medicinais, Departamento de Agricultura, Universidade Federal de Lavras (UFLA), Lavras, MG, Brasil.

ABSTRACT: Pogostemon cablin (Blanco) Benth. is an aromatic species popularly known as patchouli. The essential oil rich in patchoulol extracted from leaves is used by the pharmaceutical industries. The objective was to investigate the effects of shade nets and shading intensities on P. cablin growth, anatomy, chemical composition and essential oil content. The experiment was conducted with two types of shade nets (black and Aluminet), three light intensities (30, 50, and 70\% shading) and full sun. The different light intensities influenced the growth and the essential oil yield, and chemical composition. Patchouli plants grown in an environment with shading showed higher values for the leaf, stem, root ant total dry weights compared to full sun. At 50\% of shading, Aluminet provided gain in stem and total dry weights. Aluminet and black net at 50 and $70 \%$ of shading enhance essential oil yield. Patchoulol and pogostol contents were higher under full sun, and, black net and Aluminet at 50\% shading. The environment for patchouli cultivation can be improved by use shade nets, especially with Aluminet at $50 \%$ of shading.

Key words: anatomy, light radiation, Pogostemon cablin, patchoulol, volatile compounds.

Intensidades luminosas alteram o crescimento e óleo essencial de patchouli sob malhas

RESUMO: Pogostemon cablin (Blanco) Benth. é uma espécie aromática popularmente conhecida como patchouli. O óleo essencial rico em patchoulol extraído de folhas é utilizado pelas indústrias farmacêuticas. O objetivo foi investigar os efeitos das malhas e intensidades de sombreamento no crescimento, anatomia, composição química e teor de óleo essencial de P. cablin. O experimento foi conduzido com dois tipos de malhas (preta e Aluminet), três intensidades de luz (30, 50 e 70\% de sombreamento) e pleno sol. As diferentes intensidades de luz influenciaram o crescimento, o rendimento e a composição química do óleo essencial. Plantas de patchouli cultivadas em ambiente sombreado apresentaram maiores valores para os pesos secos de folha, caule, raiz e total em relação ao pleno sol. Com $50 \%$ de sombreamento, Aluminet proporcionou ganho de peso seco de caule e total. Aluminet e malha preta a 50 e $70 \%$ de sombreamento aumentam o rendimento do óleo essencial. Os teores de patchoulol e pogostol foram maiores a pleno sol, malha preta e Aluminet com $50 \%$ de sombreamento. O ambiente para o cultivo do patchouli pode ser melhorado com o uso de malhas de sombreamento, especialmente com Aluminet em $50 \%$ de sombreamento. Palavras-chave: anatomia, radiação luminosa, Pogostemon cablin, patchoulol, compostos voláteis.

\section{INTRODUCTION}

Pogostemon cablin (Blanco) Benth is a perennial, aromatic, erect, and branched herb, reaching a height of 0.5 to $1.2 \mathrm{~m}$. It has crossed and oval opposite leaves, measuring 5 to $10 \mathrm{~cm}$ in length and 3 to $8.9 \mathrm{~cm}$ in width, with lobed crenateserrate margins, obtuse lobes, and leaf apexes. The flowers are white, bisexual, zygomorphic, and dichlamydeous, with apentamericgamosepalous calyx and a bicarpellary superior ovaryn (SWAMY \& SINNIAH, 2016). It is traditionally named as patchouli. The essential oil extracted from $P$. cablin leaves is rich in terpenes, with patchoulol being the most important constituent (LI et al., 2021). This essential oil is widely used by the cosmetics and perfume industries because of its woody fragrance and fixative properties (VAN BEEK \& JOULAIN, 2018). Furthermore, antifungal, anthelmintic, and antitrypanosomal biological activities are attributes of patchouli essential oil (SWAMY \& SINNIAH, 2016; PHUWAJAROANPONG et al., 2020).

Plant species respond differently to solar radiation levels (YAO et al., 2017; OLIVARES-SOTO \& BASTÍAS, 2018). According to LI et al. (2020), irradiance intensity is an essential abiotic component

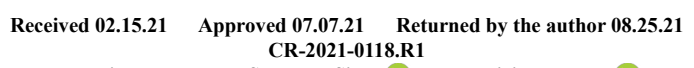


required by the plants for photosynthesis, growth, and secondary metabolic product accumulation. Still according to these authors, the adaptation of the plant's morphology, anatomy and physiological functions for changes in abiotic can influence the accumulation of secondary metabolites. Radiation affects the assimilation of carbon and; consequently, the production of essential oils in plants, as the synthesis of these oils involves biochemical pathways from the primary metabolism (THAKUR \& KUMAR, 2021). Therefore, improving the yield and medicinal properties of plants can be achieved through appropriate adjustments to the amount of light (LI et al., 2020).

The use of shade nets has altered the production of the biomass and secondary metabolites and has induced physiological and biochemical changes in medicinal plant species (MARTINS et al., 2008; MATOS et al., 2009; RIBEIRO et al., 2018; AMBUJAVALLI et al., 2019). According to ORENSHAMIR et al. (2001), black shade net is considered neutral and helps reduce the incidence of radiation on plants, without influencing the spectral quality of the light. Another type of shade net that has been adopted in Brazil is Aluminet. This shade net enables the formation of several microclimates based on the temperature adjustment between day and night, according to the shade net used. Aluminet is able to reflect and redirect sunlight, increasing light uptake by plants resulting in gain in photosynthesis. In addition, these nets protect plants from excessive solar radiation and conserve heat inside the environment (COSTA et al., 2012). THAKUR \& KUMAR (2021) concluded that in the climate change era and as per the need of the herbs, aromatic products and perfumery industry, substitution of synthetic fertilizers and poor agronomic techniques with microclimate modification can be considered to enhance the quality of products. Application of various propagation strategies, including crop management and cultivation practices are highlighted for better improvement of patchouli cultivation in the field on a large scale (SWAMY \& SINNIAH, 2016).

Due to the importance of essential oil $P$. cablin to perfume, cosmetics, and pharmaceutical industries, and due protected system allow gain productivity and quality of the plants using fewer amounts of phytosanitary products, it was hypothesized the nets may increase biomass and essential oil production. Accordingly, the objective was to investigate the effects of shade nets and shading intensities on $P$. cablin growth, anatomy, chemical composition and essential oil content.

\section{MATERIALS AND METHODS}

\section{Cultivation and growth parameters}

Plants of the patchouli (genotype POG002) were collected in the medicinal garden of Federal University of Sergipe, São Cristóvão, SE, Brazil. In the Herbarium of the Federal University of Sergipe, the voucher specimen $\left(\mathrm{n}^{\circ} .13,170\right)$ was confirmed. The scions were produced through micropropagation using axillary buds inoculated in MS medium according to RIBEIRO et al. (2018). The experiments were conducted at the Tissue and Medicinal Plant Culture Laboratory and the "Gota de Esperança" Farm, Department of Agriculture, Federal University of Lavras (UFLA), Lavras, MG, Brazil, during one harvest time (150 days).

The plants were cultivated under two types of shade nets (Aluminet and black), three shading levels (30,50, and 70\%) and full sunlight. The shading levels $30,50,70 \%$, and full sun had the following intensities: $1583,1131,678$, and $2361 \mu \mathrm{mol} \mathrm{m} \mathrm{m}^{-2} \mathrm{~s}^{-1}$. The light intensity was measured by a QSO-S Procheck + Sensor-PAR Photon Flux (Decagon Devices-Pullman-WashingtonUSA). The pots were distributed in a completely randomized design, factorial scheme with two types of shade nets (Aluminet and black net), three levels of shading (30,50 and 70\%) and one additional treatment (full sun). Five replicates was adopted and each replicate consisting of an average of four pots $\left(1\right.$ plant pot $\left.^{-1}\right)$. A total of 160 pots were randomly distributed among the experimental areas under shading (a structure of $2 \times 2 \mathrm{~m}$ ) and in full sun, with each treatment comprising 20 pots. Growth evaluations were performed 150 days after planting and the samples were dried in a forced-air oven at $40{ }^{\circ} \mathrm{C}$ untill constant weight was reached, approximately five days. The leaf (LDW), stem (SDW), root (RDW), and total dry weight (TDW) were measured on balance. The root-to-shoot ratio (R:S) was obtained by dividing the root dry weight by the sum of the dry weight of the stem and leaf (shoot dry weight). The leaf area (LA) was analyzed using an electronic LI - 3100-LICOR leaf area meter. Five expanded leaves of the third node from the top were randomly selected from each replicate. Leaf area ratio (LAR - ratio between total leaf area per plant and total dry weight), specific leaf area (SLA - ratio between total leaf area per plant and leaf dry weight) and leaf weight ratio (LWR - ratio between total leaf weight per plant and total dry weight per plant) were calculated according to the equations proposed by BENINCASA (2003). 


\section{Anatomy of leaves}

Samples of fully expanded leaves of the third node from the top of the plant were harvested and fixed to study the anatomy of leaf. The anatomical studies were performed according to RIBEIRO et al. (2018). Fragments measuring 2 x $5 \mathrm{~mm}$ were collected from the median region of the leaf blade and fixed in modified Karnovsky's fixative $(2.5 \%$ glutaraldehyde, $2.5 \%$ formaldehyde in $0.05 \mathrm{M}$ sodium cacodylate buffer, $\mathrm{pH} 7.2,0.001 \mathrm{M}$ $\mathrm{CaCl}_{2}$ ). Paradermal sections were washed in sodium cacodylate buffer three times, post fixed in $1 \%$ osmium tetroxide for $2 \mathrm{~h}$, and washed twice for 15 minutes with distilled water. The material selected for scanning microscopy was dehydrated in an acetone dehydration series $(25,50,75,90$, and 100\%) for 10 minutes each. To obtain cross sections, the samples were immersed in $30 \%$ glycerol in distilled water for 30 minutes, frozen in liquid nitrogen, and cut with a scalpel. These sections were post fixed in osmium tetroxide. Then, this material was critical point dried (BAL-TEC, DPC-030 model, Principality of Liechtenstein), mounted on aluminum stubs with double-sided tape, and then coated in gold using a sputter coater (BAL-TEC, model SCD-050, Principality of Liechtenstein). The analyses of all the sections were carried out in a scanning electron microscope (LEO, model EVO 40 XVP, CambridgeUK). Thickness of the adaxial epidermis (ADE), abaxial epidermis (ABE), cuticle (CUT), palisade parenchyma (PP), spongy parenchyma (SP) and leaf blade (LB), and number of trichomes in the adaxial epidermis (TAD) and in the abaxial epidermis (TAB) were determined in the cross sections.

\section{Essential oil extraction and the chemical analysis of the essential oil}

Hydrodistillation in a modified Clevenger apparatus was used to extract the essential oil of the samples for 90 minutes. Five dry samples of each treatment contained $70 \mathrm{~g}$ of leaves and $40 \mathrm{~g}$ of stems. The essential oil content was expressed as content ( $\mathrm{g}$ of oil in $100 \mathrm{~g}^{-1}$ of dry weight) and the yield in $\mathrm{g}$ plant $^{-1}$. Quantitative analysis of the essential oil was carried out by gas chromatography with a Flame Ionization Detector (GC-FID) on an Agilent ${ }^{\circledR} 7890$ system according to RIBEIRO et al. (2018). Helium gas was used as the carrier gas at a flow rate of 1.0 $\mathrm{mL} / \mathrm{min}$; the injector and detector temperatures were maintained at $240{ }^{\circ} \mathrm{C}$. The initial temperature was $100{ }^{\circ} \mathrm{C}$, followed by a temperature ramp to 180 ${ }^{\circ} \mathrm{C}$ at a rate of $3{ }^{\circ} \mathrm{C} / \mathrm{min}$, ending with a temperature ramp to $240{ }^{\circ} \mathrm{C}$ at a rate of $10{ }^{\circ} \mathrm{C} / \mathrm{min}$. The oil was diluted with ethyl acetate ( $1 \% \mathrm{v} / \mathrm{v})$ and automatically injected into the chromatograph using an injection volume of $1 \mu \mathrm{Lin}$ the split mode at an injection ratio of 50:1. The contents of the eluted constituents were expressed as the mean percentage area relative to the chromatographic peaks \pm the standard deviation of the samples analyzed.

The qualitative analyses of the oil were performed by gas chromatography with mass spectrometry (CG-MS). An Agilent ${ }^{\mathbb{B}}$ 5975C system was used, operated by electron impact ionization at 70 $\mathrm{eV}$, in scanning mode at a sampling rate of $1.0 \mathrm{scan} / \mathrm{s}$, with a mass acquisition interval of $40-400 \mathrm{~m} / \mathrm{z}$. The chromatographic conditions were the same as those used in the quantitative analyses. The chemical constituents were identified by comparing mass spectra from the NIST/EPA/NIH library database (NIST, 2008) and the literature (DEGUERRY et al., 2006).

\section{Statistical analysis}

Statistical analyses of the observed data were performed in $\mathrm{R}$ software. The means of the treatments were analyzed by Scott-Knott test at 5\% probability. The software Statistica ${ }^{\circledR}$, version 13.5 (StatSoft - Tulsa, USA), was used for the principal component analysis (PCA). Standardized data of three replicate of the identified chemical compounds and respective contents were transformed by the PCA in orthogonal latent variables, which are linear combinations of all original variables and were presented in biplot graphic.

\section{RESULTS AND DISCUSSION}

\section{Growth analysis}

The different types of shade nets and light intensities significantly influenced the growth variables of $P$. cablin (Table 1). The highest dry weights (leaf, stem, root and total) were obtained with use of shade net compared to full sun. Excess of solar radiation can be considered as a stress factor to reduce the physiological and morphological parameters of plants (THAKUR \& KUMAR, 2021). The plants grown with use of shade net $(42.64 \mathrm{~g})$ showed a gain of $180 \%$ in LDW relative to the crop under full sun $(23.68 \mathrm{~g})$, while 50 and $70 \%$ shading (Aluminet or black net) enabled even greater gains in relation to $30 \%$. In P. cablin, the leaves are the parts of the plant with greater commercial interest because of their higher essential oil content. Patchouli is an industrially valued aromatic medicinal plant currently having a huge demand for its essential oil (SWAMY \& SINNIAH, 2016). At 50\% of shading, 
Table 1 - Leaf dry weight (LDW), stem dry weight (SDW), root dry weight (RDW), total dry weight (TDW) and root-to-shoot ratio (R:S) of Pogostemon cablin as a function of cultivation under different shades net and light intensities, after 150 days.

\begin{tabular}{|c|c|c|c|c|c|c|c|c|c|c|}
\hline \multirow{2}{*}{$\begin{array}{l}\text { Light } \\
\text { intensities } \\
(\%)\end{array}$} & \multicolumn{2}{|c|}{---------LDW (g)------- } & \multicolumn{2}{|c|}{--------SDW (g)-------- } & \multicolumn{2}{|c|}{------RDW (g)------- } & \multicolumn{2}{|c|}{--------TDW (g)------ } & \multicolumn{2}{|c|}{------------R:S---------- } \\
\hline & Aluminet & Black net & Aluminet & Black net & Aluminet & Black net & Aluminet & Black net & Aluminet & Black net \\
\hline 30 & $40.97 \mathrm{Ba}$ & $32.60 \mathrm{Ba}$ & $20.41 \mathrm{Ca}$ & $27.67 \mathrm{Aa}$ & $11.96 \mathrm{Aa}$ & $15.37 \mathrm{Aa}$ & $64.97 \mathrm{Ca}$ & 84,02 Aa & $0.19 \mathrm{Aa}$ & $0.25 \mathrm{Aa}$ \\
\hline 50 & $43.12 \mathrm{Aa}$ & $50.17 \mathrm{Aa}$ & $45.81 \mathrm{Aa}$ & $27.34 \mathrm{Ab}$ & $17.07 \mathrm{Aa}$ & $14.95 \mathrm{Aa}$ & $113.04 \mathrm{Aa}$ & $85.41 \mathrm{Ab}$ & $0.19 \mathrm{Aa}$ & $0.19 \mathrm{Aa}$ \\
\hline 70 & $43.16 \mathrm{Aa}$ & $45.84 \mathrm{Aa}$ & $35.70 \mathrm{Ba}$ & $37.21 \mathrm{Aa}$ & $13.01 \mathrm{Aa}$ & $14.24 \mathrm{Aa}$ & $94.55 \mathrm{Ba}$ & $94.61 \mathrm{Aa}$ & $0.16 \mathrm{Ba}$ & $0.17 \mathrm{Ba}$ \\
\hline Fatorial & \multicolumn{2}{|c|}{---------42.64 A--------- } & \multicolumn{2}{|c|}{---------32.36 A-------- } & \multicolumn{2}{|c|}{--------14.44 A------- } & \multicolumn{2}{|c|}{-------89.43 A-------- } & \multicolumn{2}{|c|}{---------0.20 B-------- } \\
\hline Full sun & \multicolumn{2}{|c|}{------23.68 B-------- } & \multicolumn{2}{|c|}{-------12.31 B------- } & \multicolumn{2}{|c|}{-------11.85 B------- } & \multicolumn{2}{|c|}{-------47.84 B-------- } & \multicolumn{2}{|c|}{----0.33 A----- } \\
\hline
\end{tabular}

Means followed by different uppercase letters in the columns, statistically differ by the Scott-Knott test $(\mathrm{P}<0.05)$; Means followed by different lowercase letters in the rows, statistically differ by the Scott-Knott test $(\mathrm{P}<0.05)$.

Aluminet provided gain in stem and total dry weights compared to black net. Also, visually the Aluminet at $50 \%$ of shading provided plants more vigorous (Figure 1). However, The stem (32.36 g), root $(14.44 \mathrm{~g})$, and total dry weights $(89.43 \mathrm{~g}) \mathrm{had}$ higher values when the plants were grown under shade nets compared to the additional treatment (full sun) (Table 1).

The morph-physiological responses of plants depend not only on the presence or absence of light but also on the variations in light intensity
(MARTINS et al., 2008). Photosynthesis is one of the most sensitive metabolic processes as there is a direct and close relationship between biomass, yield productivity and their photosynthetic rates to different light conditions (THAKUR \& KUMAR, 2021). According to SWAMY \& SINNIAH (2016), patchouli grows well under shaded, well-drained, fertile soil with evenly distributed rainfall or under assured periodic irrigation. In this research, it was observed by $\mathrm{R}: \mathrm{S}$ relation that patchouli plants grown in full sun allocated a greater amount of

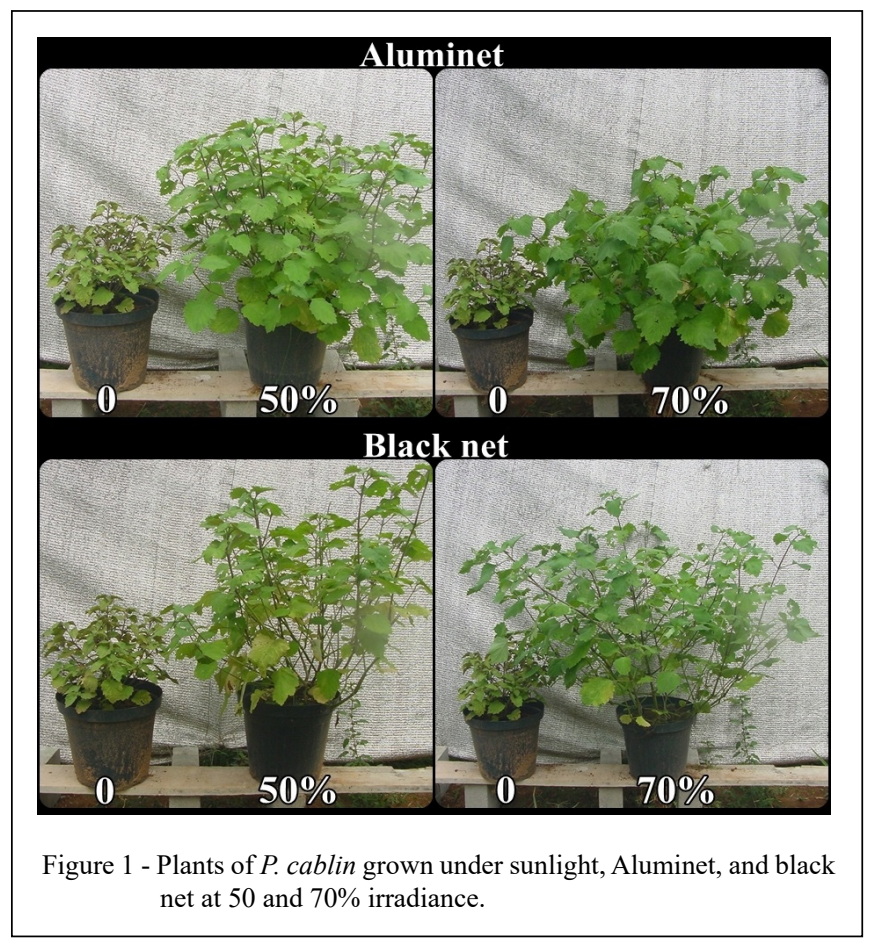

Ciência Rural, v.52, n.5, 2022. 
photoassimilates to the roots than the stem (0.32) compared to the plants cultivated under shade nets (0.19). This preferential allocation of biomass for the root system was also reported in Catharanthus roseus (L.) G. Don (MELO \& ALVARENGA, 2009), Artemisia vulgaris L. (OLIVEIRA et al., 2009) and Ocimum gratissimum L. (MARTINS et al., 2008).

For the physiological variables, a significant effect of types of shade nets and light intensities was observed on TLA, LAR, SLA, and LWR (Table 2). In black net, the lower solar irradiance $(70 \%$ of shading) resulted in a higher TLA value $\left(57.05 \mathrm{~cm}^{2}\right)$, statistically similar to Aluminet in 50 and $70 \%$ of shading (49.33 and $57.39 \mathrm{~cm}^{2}$, respectively). Shaded environments induced plants to expand their leaves to increase the area of energy capture. This fact can also be confirmed when analyzing LAR, where the increase (0.61 and $0.59 \mathrm{~cm}^{2} \mathrm{mg}^{-1}$ ) represents a better adaptation of the plant to low light conditions $(70 \%$ of shading), regardless of net type. The highest values of SLA (1.26 and $\left.1.33 \mathrm{~cm}^{2} \mathrm{mg}^{-1}\right)$ were observed in plants under Aluminet and black net at highest shading intensity (70\%). The SLA can be used to correlate leaf area and leaf dry weight. According to EVANS \& POORTER (2001), the increase in SLA is the most important factor in maximizing the carbon gain per unit of leaf mass under low light conditions. Lower values $(0.44$ and $0.45)$ of LWR occurred in plants grown without Aluminet at $50 \%$ of shading and black net at $70 \%$ of shading. According to BENINCASA (2003), the LWR represents the production of leaves via photosynthesis because this biomass is not used for respiration or exported to other organs.

\section{Anatomy of leaves}

Plants cultivated under various light intensities showed a differential behavior for the epidermis (THAKUR \& KUMAR, 2021). In this research, the cuticle $(6.55 \mu \mathrm{m})$, palisade parenchyma $(51.72 \mu \mathrm{m})$, spongy parenchyma $(169.12 \mu \mathrm{m})$ and leaf blades $(289.98 \mu \mathrm{m})$ were thicker in plants grown under full sun (Table 3, Figure 2). The thinnest leaf blades (149.90 and $157.05 \mu \mathrm{m}$ ) were observed, respectively, with the use of Aluminet at $70 \%$ of shading and black net at $50 \%$ of shading. The scanning electron microscopy observations showed variations in the thickness of the epidermis and the number of trichomes, in the adaxial and abaxial cross sections depending on the culture environments (Table 4). Plants grown in full sun showed adaxial $(24.47 \mu \mathrm{m})$ and abaxial $(14.40 \mu \mathrm{m})$ epidermis thickness greater than plants under Aluminet and black net. The presence of trichomes on the adaxial leaf surface was higher in full sun cultivation (72) compared to nets (53), with no difference on the abaxial (Table 4). The increase in trichome on the adaxial surface is a way to protect the leaf from the intensity of radiation by keeping the leaf at a milder temperature. The increase in the thickness of the leaf tissues observed in plants that grow in full sun may be a way of reducing and/or preventing damages caused by the excess light to the photosynthetic apparatus, thus preserving photosynthesis (MATOS et al., 2009). Thicker cuticles can increase the reflectance of the leaves and improve efficiency in light interception (CHAZDON \& KAUFMANN, 1993). According to CASTRO et al. (2005) and LEE et al. (2000), the length of the cells of the palisade parenchyma and the number of cell layers in the spongy parenchyma vary according to the different levels of shading and of irradiance.

Table 2 - Total leaf area (TLA), leaf area ratio (LAR), specific leaf area (SLA) and leaf weight ratio (LWR) of Pogostemon cablin as a function of cultivation under different shades net and light intensities, after 150 days.

\begin{tabular}{|c|c|c|c|c|c|c|c|c|}
\hline \multirow{2}{*}{$\begin{array}{l}\text { Light } \\
\text { intensities } \\
(\%)\end{array}$} & \multicolumn{2}{|c|}{ 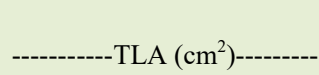 } & \multicolumn{2}{|c|}{------LAR $\left(\mathrm{cm}^{2} \mathrm{mg}^{-1}\right)------$} & \multicolumn{2}{|c|}{------SLA $\left(\mathrm{cm}^{2} \mathrm{mg}^{-1}\right)-----$} & \multicolumn{2}{|c|}{ 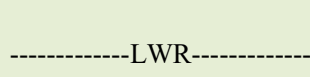 } \\
\hline & Aluminet & Black net & Aluminet & Black net & Aluminet & Black net & Aluminet & Black net \\
\hline 30 & $28.36 \mathrm{Ba}$ & $37.35 \mathrm{Ba}$ & $0.46 \mathrm{Ba}$ & $0.44 \mathrm{Ba}$ & $0.91 \mathrm{Ba}$ & $0.91 \mathrm{Ba}$ & $0.50 \mathrm{Aa}$ & $0.48 \mathrm{Aa}$ \\
\hline 50 & $49.33 \mathrm{Aa}$ & $35.52 \mathrm{Bb}$ & $0.44 \mathrm{Ba}$ & $0.41 \mathrm{Ba}$ & $1.01 \mathrm{Ba}$ & $0.82 \mathrm{Ba}$ & $0.44 \mathrm{Ba}$ & $0.50 \mathrm{Aa}$ \\
\hline 70 & $57.39 \mathrm{Aa}$ & $57.05 \mathrm{Aa}$ & $0.61 \mathrm{Aa}$ & $0.59 \mathrm{Aa}$ & $1.26 \mathrm{Aa}$ & $1.33 \mathrm{Aa}$ & $0.48 \mathrm{Aa}$ & $0.45 \mathrm{Bb}$ \\
\hline Fatorial & \multicolumn{2}{|c|}{-----------44.17 A------------ } & \multicolumn{2}{|c|}{-------------0.49 A------------ } & \multicolumn{2}{|c|}{------------1.04 A----------- } & \multicolumn{2}{|c|}{-----------0.48 A-----------. } \\
\hline Full sun & \multicolumn{2}{|c|}{----------17.23 B------------ } & \multicolumn{2}{|c|}{ 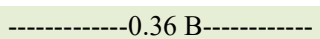 } & \multicolumn{2}{|c|}{ 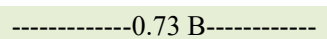 } & \multicolumn{2}{|c|}{-----------0.49 A------------ } \\
\hline
\end{tabular}

Means followed by different uppercase letters in the columns, statistically differ by the Scott-Knott test $(\mathrm{P}<0.05)$; Means followed by different lowercase letters in the rows, statistically differ by the Scott-Knott test $(\mathrm{P}<0.05)$. 
Table 3 - Thickness of cuticle (CUT); palisade parenchyma (PP); spongy parenchyma (SP); leaf blade (LB) of Pogostemon cablin as a function of cultivation under different shades net and light intensities, after 150 days.

\begin{tabular}{|c|c|c|c|c|c|c|c|c|}
\hline \multirow{2}{*}{$\begin{array}{l}\text { Light } \\
\text { intensities (\%) }\end{array}$} & \multicolumn{2}{|c|}{--------CUT $(\mu \mathrm{m})-------$} & \multicolumn{2}{|c|}{ 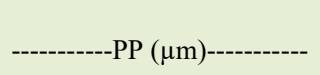 } & \multicolumn{2}{|c|}{----------SP $(\mu \mathrm{m})----------$} & \multicolumn{2}{|c|}{----------LB $(\mu \mathrm{m})------$} \\
\hline & Aluminet & Black net & Aluminet & Black net & Aluminet & Black net & Aluminet & Black net \\
\hline 30 & $1.55 \mathrm{Cb}$ & $2.36 \mathrm{Ba}$ & $41.67 \mathrm{Cb}$ & $52.39 \mathrm{Aa}$ & $83.97 \mathrm{Ab}$ & $94.61 \mathrm{Aa}$ & $161.55 \mathrm{Bb}$ & $185.80 \mathrm{Aa}$ \\
\hline 50 & $2.91 \mathrm{Aa}$ & $2.35 \mathrm{Bb}$ & $47.62 \mathrm{Ab}$ & $52.31 \mathrm{Aa}$ & $81.26 \mathrm{Ba}$ & $71.21 \mathrm{Cb}$ & $163.40 \mathrm{Aa}$ & $157.05 \mathrm{Cb}$ \\
\hline 70 & $2.35 \mathrm{Bb}$ & $3.00 \mathrm{Aa}$ & $44.62 \mathrm{Bb}$ & $51.25 \mathrm{Aa}$ & $56.76 \mathrm{Cb}$ & $79.34 \mathrm{Ba}$ & $149.90 \mathrm{Cb}$ & $159.25 \mathrm{Ba}$ \\
\hline Fatorial & \multicolumn{2}{|c|}{-----------2.42 B---------- } & \multicolumn{2}{|c|}{-------------48.31 B----------- } & \multicolumn{2}{|c|}{------------77.86 B------------ } & \multicolumn{2}{|c|}{-------------161.49 B---------- } \\
\hline Full sun & \multicolumn{2}{|c|}{-----------6.55 A---------- } & \multicolumn{2}{|c|}{-----------51.72 A----------- } & \multicolumn{2}{|c|}{----------169.12 A---------- } & \multicolumn{2}{|c|}{-------------289.98 A---------- } \\
\hline
\end{tabular}

Means followed by different uppercase letters in the columns, statistically differ by the Scott-Knott test $(\mathrm{P}<0.05)$; Means followed by different lowercase letters in the rows, statistically differ by the Scott-Knott test $(\mathrm{P}<0.05)$.

The palisade and spongy parenchyma are tissues with a great capacity of response to the light stimulus, thus influencing the leaf thickness (CASTRO et al., 2005). However, these responses vary according to light intensity rather than light quality, since the spectral quality of the light is not able to affect the contribution of the tissue layers to the total leaf thickness or the mesophyll composition

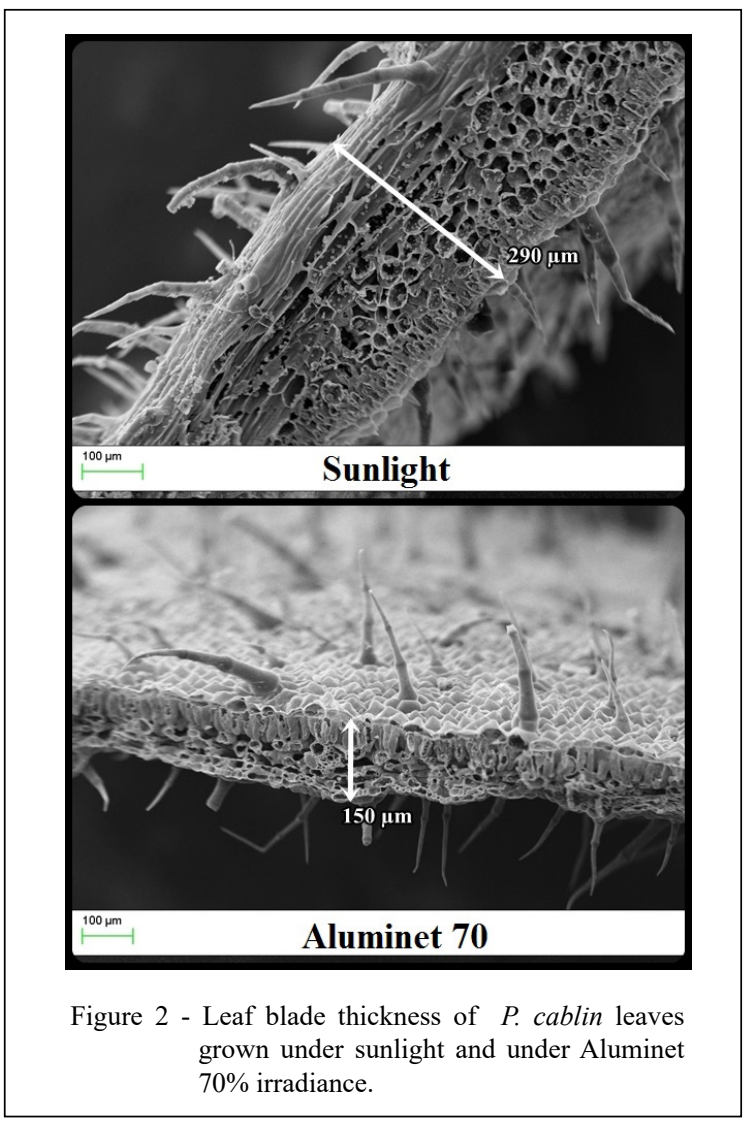

(LEE et al., 2000). In this study, plants grown under full sun showed higher thickness of palisade parenchyma $(51.72 \mu \mathrm{m})$ and spongy parenchyma $(169.12 \mu \mathrm{m})$ than under nets conditions (48.31 and $77.86 \mu \mathrm{m}$, respectively) (Table 3). Parenchyma cells of plants grown under nets conditions are comparatively less thick as compared with full sun (THAKUR \& KUMAR, 2021). This reduction in the thickness of the leaves of shaded plants is possibly due to the difference in the distribution and consumption of photoassimilates for leaf expansion, as observed in this study the leaf area under net $\left(44.17 \mathrm{~cm}^{2}\right)$ was higher compared to full sun $(17.23$ $\mathrm{cm}^{2}$ ) (Table 2). According to TAIZ \& ZEIGER (2017), the properties of the palisade parenchyma cells allow the direct passage of light, whereas the properties of the spongy parenchyma cells favor light scattering, thus determining uniform light absorption through the leaf.

\section{Essential content, yield, and chemical composition}

Significant differences were observed between the mean contents and yield of essential oil extracted from the leaves and stems of P. cablin (Table 5). The oil content of the leaves $(0.65-1.16 \%)$ was higher than that in the stem $(0.06-0.16 \%)$. Plants grown under Aluminet and black net with 50 and $70 \%$ shading exhibited the highest essential oil content in the leaves and higher essential oil yield. Conversely, cultivation in full sun led to the lowest leaf $(0.78 \%)$ and stem content $(0.06 \%)$ and the lowest yield $\left(0.17 \mathrm{~g} \mathrm{plant}^{-1}\right)$. Normally, it is possible to observe a correlation between the number of trichomes and the essential oil content. In this study the cultivation in full sun allowed a greater number of trichomes (72 trichomes) in relation to the meshes 
Table 4 - Thickness of the adaxial epidermis (ADE) and abaxial epidermis (ABE), and number of trichomes in the adaxial epidermis (TAD) and in the abaxial epidermis (TAB) of Pogostemon cablin as a function of cultivation under different shades net and light intensities, after 150 days.

\begin{tabular}{|c|c|c|c|c|c|c|c|c|}
\hline \multirow[t]{2}{*}{ Light intensities (\%) } & \multicolumn{2}{|c|}{-------ADE $(\mu \mathrm{m})$-------- } & \multicolumn{2}{|c|}{------ABE $(\mu \mathrm{m})-------$} & \multicolumn{2}{|c|}{--------TAD (number)-------- } & \multicolumn{2}{|c|}{-------TAB (number)------- } \\
\hline & Aluminet & Black net & Aluminet & Black net & Aluminet & Black net & Aluminet & Black net \\
\hline 30 & $15.67 \mathrm{Bb}$ & $22.92 \mathrm{Aa}$ & $14.67 \mathrm{Bb}$ & $16.23 \mathrm{Aa}$ & $44 \mathrm{Cb}$ & $68 \mathrm{Aa}$ & $131 \mathrm{Aa}$ & $82 \mathrm{Ab}$ \\
\hline 50 & $10.38 \mathrm{Cb}$ & $17.38 \mathrm{Ba}$ & $11.99 \mathrm{Cb}$ & $13.92 \mathrm{Ba}$ & $74 \mathrm{Aa}$ & $41 \mathrm{Bb}$ & $67 \mathrm{~B} \mathrm{Aa}$ & $53 \mathrm{Bb}$ \\
\hline 70 & $25.85 \mathrm{Aa}$ & $22.70 \mathrm{Ab}$ & $16.70 \mathrm{Aa}$ & $16.05 \mathrm{Aa}$ & $51 \mathrm{Ba}$ & $42 \mathrm{Bb}$ & $56 \mathrm{C} \mathrm{Aa}$ & $24 \mathrm{Cb}$ \\
\hline Fatorial & \multicolumn{2}{|c|}{---------19.15 B---------- } & \multicolumn{2}{|c|}{----------14.93 B--------- } & \multicolumn{2}{|c|}{---------------53 B--------------- } & \multicolumn{2}{|c|}{--------------69 A-------------- } \\
\hline Full sun & \multicolumn{2}{|c|}{---------24.47 A--------- } & \multicolumn{2}{|c|}{----------16.40 A--------- } & \multicolumn{2}{|c|}{--------------72 A-------------- } & \multicolumn{2}{|c|}{-------------56 A------------ } \\
\hline
\end{tabular}

Means followed by different uppercase letters in the columns, statistically differ by the Scott-Knott test $(\mathrm{P}<0.05)$; Means followed by different lowercase letters in the rows, statistically differ by the Scott-Knott test $(\mathrm{P}<0.05)$.

(53) (Table 4). But, this higher number of trichomes did not provide a higher content of essential oil, and cultivation in full sun $(0.78 \%)$ was similar to that of plants grown in nets $(0.90 \%)$ (Table 5$)$. This is due that the glandular trichomes are reported on the surface of the leaves, becoming more exposed to damage and losses in the essential oil content, caused by higher temperatures.

Essential oils are an important group of economic products of $P$. cablin (VAN BEEK \& JOULAIN, 2018). Presence of essential oil in the glandular trichomes and in the peltate trichomes, and they also present essential oil-producing glands distributed throughout the mesophyll and in greater contact with the palisade parenchyma (SWAMY \& SINNIAH, 2016). The secretion of the essential oil seems to occur through ducts that lead to the adaxial portion of the leaf (DUARTE \& LOPES, 2005; GUO et al., 2013).

The light intensity changes the chemical composition of the essential oils of medicinal plants (Table 6). In total, 14 chemical constituents were identified, totaling more than $93 \%$ of the total constituents of the essential oils analyzed. The chemical composition of the essential oil of $P$. cablin leaves consisted entirely of sesquiterpenes, except for 1-octen-3-ol alcohol, which was present at concentrations of 0.19 to $0.61 \%$. The constituents $\alpha$-guaiene, panasinsen, $\alpha$-bulnesene, patchoulol, and pogostol represented approximately $84 \%$ of the total chemical composition.

In the present study, the patchoulol was the major constituent, with levels of 58.16 to $66.31 \%$. Among the sesquiterpene-rich essential oils in the

Table 5 - Essential oil content and yield of Pogostemon cablin as a function of cultivation under different shades net and light intensities, after 150 days.

\begin{tabular}{|c|c|c|c|c|c|c|}
\hline \multirow{2}{*}{$\begin{array}{l}\text { Light } \\
\text { intensities (\%) }\end{array}$} & \multicolumn{2}{|c|}{----------Leaves Content (\%)-------- } & \multicolumn{2}{|c|}{----------Stem Content (\%)----------- } & \multicolumn{2}{|c|}{----------Yield (g planta'-1)--------- } \\
\hline & Aluminet & Black net & Aluminet & Black net & Aluminet & Black net \\
\hline 30 & $0.65 \mathrm{Ba}$ & $0.87 \mathrm{Ba}$ & $0.10 \mathrm{Ba}$ & $0.11 \mathrm{Ba}$ & $0.24 \mathrm{Ba}$ & $0.32 \mathrm{Ba}$ \\
\hline 50 & $1.16 \mathrm{Aa}$ & $0.91 \mathrm{Aa}$ & $0.16 \mathrm{Aa}$ & $0.12 \mathrm{Aa}$ & $0.54 \mathrm{Aa}$ & $0.43 \mathrm{Aa}$ \\
\hline 70 & $0.92 \mathrm{Aa}$ & $0.91 \mathrm{Aa}$ & $0.10 \mathrm{Ba}$ & $0.10 \mathrm{Ba}$ & $0.41 \mathrm{Aa}$ & $0.40 \mathrm{Aa}$ \\
\hline Fatorial & \multicolumn{2}{|c|}{------------------0.90 A----------------- } & \multicolumn{2}{|c|}{------------------0.12 A----------------- } & \multicolumn{2}{|c|}{-----------------0.39 A----------------. } \\
\hline Full sun & \multicolumn{2}{|c|}{ 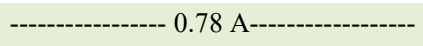 } & \multicolumn{2}{|c|}{ 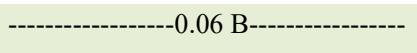 } & \multicolumn{2}{|c|}{----------------0.17 B--------------- } \\
\hline
\end{tabular}

Means followed by different uppercase letters in the columns, statistically differ by the Scott-Knott test $(\mathrm{P}<0.05)$; Means followed by different lowercase letters in the rows, statistically differ by the Scott-Knott test $(\mathrm{P}<0.05)$.

Ciência Rural, v.52, n.5, 2022. 
Table 6 - Percentage of volatile constituents of the essential oil from Pogostemon cablin leaves as a function of cultivation under different shades net and light intensities, after 150 days.

\begin{tabular}{|c|c|c|c|c|c|c|c|c|}
\hline Constituents & $\mathrm{RT}^{a}$ & Full sun & $\begin{array}{c}\text { Aluminet } \\
30 \%\end{array}$ & $\begin{array}{c}\text { Black net } \\
30 \%\end{array}$ & $\begin{array}{c}\text { Aluminet } \\
50 \%\end{array}$ & $\begin{array}{c}\text { Black net } \\
50 \%\end{array}$ & $\begin{array}{c}\text { Aluminet } \\
70 \%\end{array}$ & $\begin{array}{c}\text { Black net } \\
70 \%\end{array}$ \\
\hline 1-octen-3-ol & 6.24 & $0.61 \pm 0.06$ & $0.42 \pm 0.19$ & $0.33 \pm 0.18$ & $0.29 \pm 0.08$ & $0.33 \pm 0.00$ & $0.23 \pm 0.08$ & $0.19 \pm 0.01$ \\
\hline$\beta$-patchoulene & 7.34 & $0.80 \pm 0.05$ & $1.14 \pm 0.12$ & $0.98 \pm 0.12$ & $0.87 \pm 0.14$ & $0.77 \pm 0.07$ & $1.03 \pm 0.04$ & $1.21 \pm 0.17$ \\
\hline$\alpha$-Guaiene & 9.56 & $4.57 \pm 0.32$ & $6.93 \pm 0.54$ & $6.27 \pm 0.59$ & $5.98 \pm 0.93$ & $5.69 \pm 0.44$ & $7.35 \pm 0.36$ & $8.31 \pm 1.07$ \\
\hline$\beta$-Caryophyllene & 9.80 & $1.48 \pm 0.06$ & $2.02 \pm 0.19$ & $1.79 \pm 0.21$ & $1.74 \pm 0.25$ & $1.58 \pm 0.19$ & $2.08 \pm 0.08$ & $2.31 \pm 0.36$ \\
\hline$\alpha$-Patchoulene & 10.85 & $2.11 \pm 0.09$ & $2.38 \pm 0.16$ & $2.15 \pm 0.29$ & $2.06 \pm 0.28$ & $1.86 \pm 0.14$ & $2.32 \pm 0.09$ & $2.57 \pm 0.38$ \\
\hline Panasinsen & 10.99 & $4.61 \pm 0.22$ & $5.04 \pm 0.38$ & $4.57 \pm 0.67$ & $4.34 \pm 0.58$ & $3.80 \pm 0.28$ & $4.85 \pm 0.15$ & $5.32 \pm 0.86$ \\
\hline$\gamma$-Patchoulene & 11.40 & $0.52 \pm 0.03$ & $0.55 \pm 0.04$ & $0.49 \pm 0.08$ & $0.47 \pm 0.06$ & $0.42 \pm 0.03$ & $0.53 \pm 0.02$ & $0.57 \pm 0.09$ \\
\hline$\alpha$-Humulene & 11.62 & $0.46 \pm 0.02$ & $0.62 \pm 0.05$ & $0.57 \pm 0.05$ & $0.55 \pm 0.07$ & $0.51 \pm 0.04$ & $0.64 \pm 0.02$ & $0.71 \pm 0.10$ \\
\hline$\alpha$-Bulnesene & 12.84 & $5.18 \pm 0.16$ & $8.21 \pm 0.91$ & $7.35 \pm 0.74$ & $6.76 \pm 1.04$ & $6.79 \pm 0.51$ & $8.38 \pm 0.37$ & $9.53 \pm 1.00$ \\
\hline Caryophyllene oxide & 20.64 & $1.20 \pm 0.12$ & $0.67 \pm 0.09$ & $0.77 \pm 0.16$ & $0.58 \pm 0.09$ & $0.48 \pm 0.06$ & $0.42 \pm 0.05$ & $0.33 \pm 0.01$ \\
\hline Norpatchoulenol & 24.44 & $1.40 \pm 0.13$ & $1.09 \pm 0.08$ & $0.99 \pm 0.10$ & $1.27 \pm 0.06$ & $1.05 \pm 0.02$ & $1.13 \pm 0.08$ & $1.32 \pm 0.21$ \\
\hline Patchoulol & 26.42 & $66.31 \pm 0.90$ & $60.15 \pm 2.68$ & $64.10 \pm 3.13$ & $65.34 \pm 0.07$ & $66.14 \pm 1.25$ & $61.27 \pm 1.09$ & $58.16 \pm 3.40$ \\
\hline Seychellene & 27.14 & $0.66 \pm 0.01$ & $0.70 \pm 0.13$ & $0.64 \pm 0.04$ & $0.67 \pm 0.04$ & $0.69 \pm 0.03$ & $0.62 \pm 0.01$ & $0.59 \pm 0.05$ \\
\hline Pogostol & 27.28 & $4.48 \pm 0.13$ & $3.97 \pm 0.17$ & $4.24 \pm 0.35$ & $4.33 \pm 0.33$ & $4.52 \pm 0.13$ & $3.90 \pm 0.07$ & $3.64 \pm 0.25$ \\
\hline Total identified (\%) & & 94.39 & 93.89 & 95.24 & 95.25 & 94.63 & 94.75 & 94.76 \\
\hline
\end{tabular}

Percentage of relative peak areas (mean \pm standard deviation; $\mathrm{n}=3$ ); ${ }^{a}$ Retention time on the DB-Wax column.

category "natural woody commodities", patchouli is of major importance for the fragrance industry (VAN BEEK \& JOULAIN, 2018). Despite the significant qualitative and quantitative differences in the chemical composition of the essential oil, the patchoulol contents were slightly higher in the oil of the plants grown under full sun $(66.31 \%)$ and under black net (66.14\%) and Aluminet (65.34\%) with 50\% shading. The principal components analyses confirm these results (Figure 3). Full sun, black net and Aluminet with 50\% shading possibly promoted the patchoulol synthase activity, the enzyme responsible for the synthesis of patchoulol from farnesyl-diphosphate (FPP), according to DEGUERRY et al. (2006). However, the oil yield under Aluminet and black with 50\% shading showed a gain of 3 and 2.5 times in relation to full sun, respectively. Together, PC1 and PC2 accounted for $99.36 \%$ of the variance in the five main chemical compounds in the oil extracted from the leaves. The PC1 scores showed that full sun, black net and Aluminet with 50\% shading (B150) (negative scores) were separated from black net with $70 \%$ shading (B70) (positive scores). Analysis of the loadings showed that patchoulol and pogostol were inversely correlated with the other constituents analyzed.

The compound $\alpha$-patchoulene presented a slight decrease in the patchouli leaves grown under shade net with $50 \%$ shading (1.86\%) compared to the other treatments $(2.06 \%$ to $2.57 \%)$. DONELIAN et al. (2009) reported that patchoulol and $\alpha$-patchoulene influence the quality and improve in value of essential oil in the market and have antifungal activity. Several factors can influence the composition of the patchouli essential oil, such as the quality of the leaf material, distillation method, aging of dried leaves, quality of the essential oil, plant age, and cultivation practices. Chemical variations also occur among patchouli materials from different regions; an example is the difference in patchoulol content of patchouli oils from China and Indonesia (SANT'ANA et al., 2010).

\section{CONCLUSION}

Pogostemon cablin plants cultivated in an environment with shading show higher growth parameters compared to full sun. The plants grown under Aluminet or black net of 50 and $70 \%$ of shading improve leaves weight gain and enhance essential oil content and yield. The higher patchoulol and pogostol contents in leaves are reported in plants grown under full sun, and black net and Aluminet at 50\% shading. It can be concluded that the use shade nets, mainly Aluminet at $50 \%$ of shading, can be recommended for the cultivation of patchouli under Brazilian conditions. 


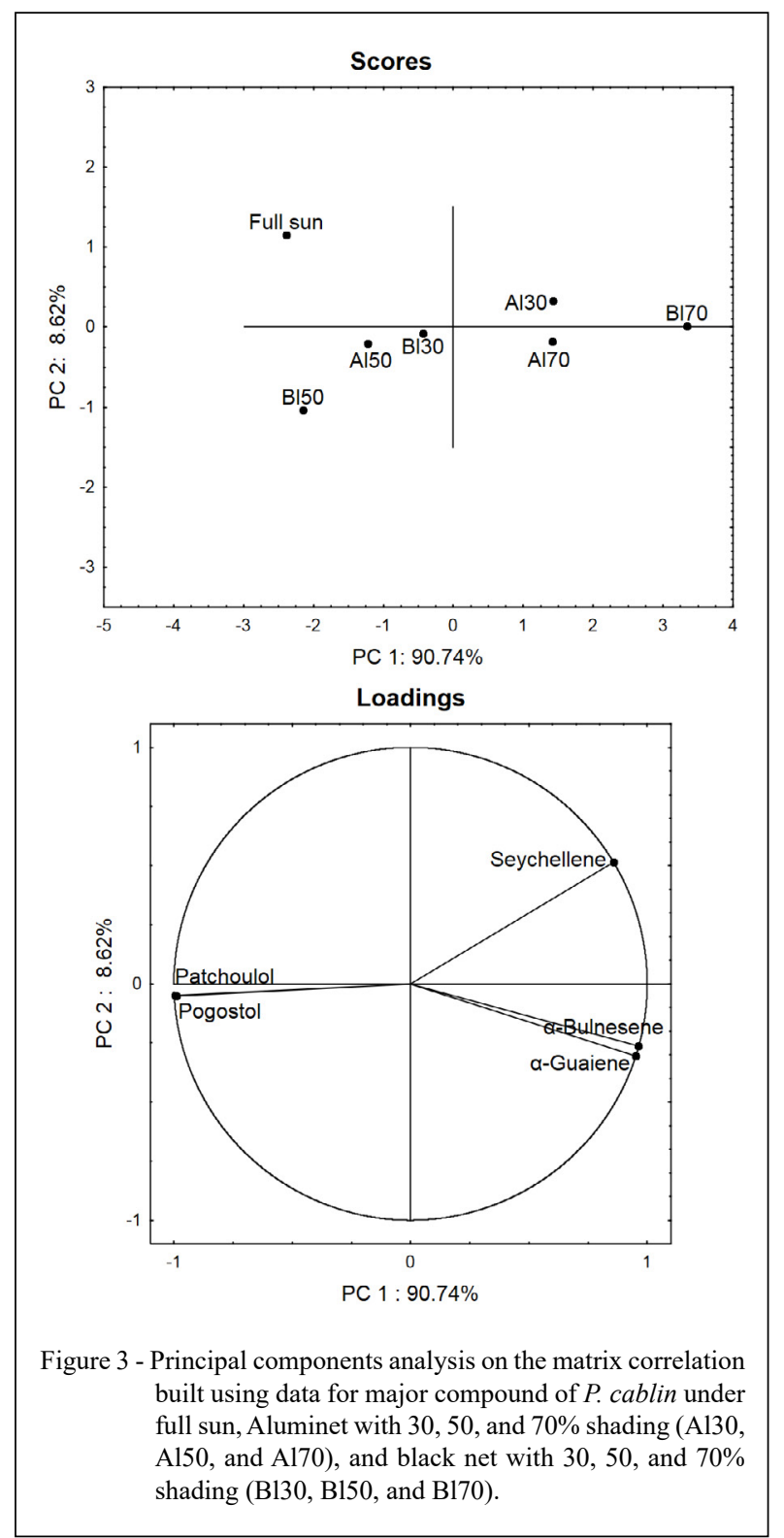

\section{ACKNOWLEDGEMENTS}

This study was financed in parts by National Council for Scientific and Technological Development (CNPq - Conselho Nacional de Desenvolvimento Científico e Tecnológico), the Minas Gerais State Research Foundation (FAPEMIG - Fundação de Pesquisa do Estado de Minas Gerais), and the Coordination for the Improvement of Higher Education Personnel (CAPES Coordenação de Aperfeiçoamento de Pessoal de Nível Superior Brasil (CAPES - Finance Code 001).

\section{DECLARATION OF CONFLICT OF INTEREST}

The authors declare no conflicts of interest.

\section{AUTHORS' CONTRIBUTIONS}

ASR performed the experiments and wrote the manuscript. SKVB and JEBPP designed the study, supervised the laboratory work and contributed to critical reading of the manuscript. ASR, AAC, WNT and ADC performed the experiments. AAC analyzed the data. All the authors have read the final manuscript and approved the submission.

\section{REFERENCES}

AMBUJAVALLI, J., et al. Assessment of growth characteristics of medicinal plants Ocimum tenuiflorum L. and Plectranthus amboinicus (Lour.) Spreng. under shade net and open conditions. European Journal of Medicinal Plants, p.1-8. 2019. Available

Ciência Rural, v.52, n.5, 2022. 
from: <https://www.journalejmp.com/index.php/EJMP/article/ view/30186>. Accessed: Jun. 18, 2020. doi: 10.9734/ejmp/2019/ v30i430186.

BENINCASA, M. M. P. Plant growth analysis. Jaboticabal: FUNEP. 2003. $41 \mathrm{p}$.

CASTRO, E. M. D., et al. Anatomical and physiological aspects of guaco plants submitted to different photoperiods. Horticultura Brasileira v.23, p.846-850. 2005. Available from: $<$ http://www.scielo.br/scielo.php?script=sci arttext\&pid=S010205362005000300031\&nrm=iso $>$. Accessed: Mar. 8, 2020. doi: $10.1590 /$ S0102-05362005000300031

CHAZDON, R. L.; S. KAUFMANN. Plasticity of leaf anatomy of two rain forest shrubs in relation to photosynthetic light acclimation. Functional Ecology, p.385-394. 1993. Available from: $\quad<$ https://www.jstor.org/stable/2390025? origin=crossref $>$. Accessed: Mar. 12, 2020. doi: 10.2307/2390025.

COSTA, A. G., et al. Vegetative growth and yield of essential oil of peppermint grown under nets. Pesquisa Agropecuária Brasileira, v.47, n.4, p.534-540. 2012. Available from: <https://www.scielo.

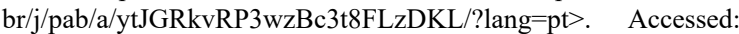
Mar. 16, 2020. doi: 10.1590/S0100-204X2012000400009.

DEGUERRY, F., et al. The diverse sesquiterpene profile of patchouli, Pogostemon cablin, is correlated with a limited number of sesquiterpene synthases. Archives of Biochemistry and Biophysics, v.454, n.2, p.123-136. 2006. Available from: <http://www.sciencedirect.com/ science/article/pii/S000398610600289X>. Accessed: Apr. 05, 2020. doi: 10.1016/j.abb.2006.08.006.

DONELIAN, A., et al. Comparison of extraction of patchouli (Pogostemon cablin) essential oil with supercritical $\mathrm{CO}_{2}$ and by steam distillation. Journal of Supercritical Fluids v.48, n. 1, p. 15 20. 2009. Available from: $<$ http://www.sciencedirect.com/science/ article/pii/S0896844608003008>. Accessed: Jun. 8, 2020. doi: 10.1016/j.supflu.2008.09.020.

DUARTE, M. D. R.; J. F. LOPES. Leaf and stem morphoanatomy of Leonurus sibiricus L., Lamiaceae. Acta Farmacéutica Bonaerense, v.24, n.1, p.68-74. 2005. Available from: <http:// www.latamjpharm.org/trabajos/24/1/LAJOP 24 1 14 QJ2U5P6594.pdf>. Accessed: May, 28, 2020.

EVANS, J. R.; H. POORTER. Photosynthetic acclimation of plants to growth irradiance: the relative importance of specific leaf area and nitrogen partitioning in maximizing carbon gain. Plant, Cell and Environment, v.24, n.8, p.755-767. 2001. Available from: $<$ http://cienciarural.web2267.uni5.net/?__store=en\&__from store $=$ default $>$. Accessed: May, 18, 2020. doi: 10.1046/j. $1365-$ 3040.2001.00724.x.

GUO, J., et al. Development and structure of internal glands and external glandular trichomes in Pogostemon cablin. PLOS ONE, v.8, n.10, p.e77862. 2013. Available from: <https://doi. org/10.1371/journal.pone.0077862>. Accessed: Mar. 02, 2020. doi: 10.1371 journal.pone.0077862.

LEE, D. W., et al. Effects of irradiance and spectral quality on leaf structure and function in seedlings of two Southeast Asian Hopea (Dipterocarpaceae) species. American Journal of Botany, v.87, n.4, p.447-455. 2000. Available from: <https://bsapubs. onlinelibrary.wiley.com/doi/abs/10.2307/2656588>. Accessed: Mar. 18, 2020. doi: 10.2307/2656588.
LI, J., et al. Identification of trihelix transcription factors in Pogostemon cablin reveals PatGT-1 negatively regulates patchoulol biosynthesis. Industrial Crops and Products, v.161, p.113182. 2021. Available from: <https://www.sciencedirect.com/ science/article/pii/S0926669020310992>. Accessed: Feb. 8, 2021. doi: $10.1016 /$ j.indcrop.2020.113182.

LI, Y., et al. The effect of developmental and environmental factors on secondary metabolites in medicinal plants. Plant Physiology and Biochemistry, v.148, p.80-89. 2020. Available from: $<$ https:// www.sciencedirect.com/science/article/pii/S0981942820300061>. Accessed: Feb. 8, 2021. doi: 10.1016/j.plaphy.2020.01.006.

MARTINS, J. R., et al. Vegetative development and essential oil content in plants of Ocimum gratissimum L. under colored nets. . Revista Brasileira de Plantas Medicinais, v.10, n.4, p.102-107. 2008. Available from: $<$ http://www.latamjpharm.org/trabajos/24/1/ LAJOP 24 1 1 8 QJ2U5P6594.pdf>. Accessed: May, 11, 2020.

MATOS, F. S., et al. Phenotypic plasticity in response to light in the coffee tree. Environmental and Experimental Botany, v.67, n.2, p.421-427. 2009. Available from: <http://www.sciencedirect. com/science/article/pii/S0098847209001439>. Accessed: Mar. 15, 2020. doi: 10.1016/j.envexpbot.2009.06.018.

MELO, A. A. M.; A. A. D. ALVARENGA. Shading of 'Pacifica White' Catharanthus roseus (L.) G. Don plants with colored nets: vegetative development. Ciência e Agrotecnologia, v.33, p.514-520. 2009. Available from: <http:// www.scielo.br/scielo.php? script $=$ sci_arttext\&pid $=\mathrm{S} 1413$ 70542009000200024\&nrm=iso $>$. Accessed: Mar. 28, 2020. doi: $10.1590 / \mathrm{S} 1413-70542009000200024$.

NIST. National Institute of Standards and Technology - Chemistry Web Book. 2008. Available from: <http://webbook.nist.gov/ chemistry/>. Accessed: Apr. 05, 2020.

OLIVARES-SOTO, H.; R. M. BASTÍAS. Photosynthetic efficiency of apples under protected shade nets. Chilean journal of agricultural research, v.78, p.126-138. 2018. Available from: $<$ https://scielo.conicyt.cl/scielo.php?script=sci arttext\&pid=S0718-58392018000100126\&nrm=iso $>$. Accessed: May, 18, 2020. doi: 10.4067/S0718-58392018000100126.

OLIVEIRA, M., et al. Biometric, anatomical and physiological aspects of Artemisia vulgaris L. grown under colored screens. Revista Brasileira de Plantas Medicinais, v.11, n.1, p.5662. 2009. Available from: May, 15, 2020. doi: 10.1590/S151605722009000100010

OREN-SHAMIR, M., et al. Coloured shade nets can improve the yield and quality of green decorative branches of Pittosporum variegatum. Journal of Horticultural Science and Biotechnology v.76, n.3, p.353-361. 2001. Available from: $<$ https://doi.org/10.1 080/14620316.2001.11511377>. Accessed: Apr. 15, 2020. doi: 10.1080/14620316.2001.11511377.

PHUWAJAROANPONG, A., et al. In vitro and in vivo antimalarial activities and toxicological assessment of Pogostemon cablin (Blanco) Benth. Journal of Evidence-Based Integrative Medicine, v.25, p.2515690X20978387. 2020. Available from: $<$ https://doi.org/10.1177/2515690X20978387>. Accessed: Mar. 8, 2020. doi: $10.1177 / 2515690 \times 20978387$.

RIBEIRO, A. S., et al. Colored shade nets induced changes in growth, anatomy and essential oil of Pogostemon cablin.

Ciência Rural, v.52, n.5, 2022. 
Anais da Academia Brasileira de Ciências, v.90, p.1823-1835. 2018. Available from: <http://www. scielo.br/scielo.php?script=sci_arttext\&pid=S000137652018000401823\&nrm=iso>. Accessed: May, 18, 2020. doi: 10.1590/0001-3765201820170299.

SANT'ANA, T. C. P. D., et al. Storage influence of dried leaves on patchouly (Pogostemon cablin Benth.) essential oil. Química Nova, v.33, p.1263-1265. 2010. Available from: $<$ http://www.scielo.br/scielo.php?script=sci_arttext\&pid=S010040422010000600008\&nrm=iso>. Accessed: May, 13, 2020. doi: $10.1590 / \mathrm{S} 0100-40422010000600008$.

SWAMY, M. K.; U. R. SINNIAH. Patchouli (Pogostemon cablin Benth.): Botany, agrotechnology and biotechnological aspects. Industrial Crops and Products, v.87, p.161-176. 2016. Available from: $\quad<$ https://www.sciencedirect.com/science/article/pii/ S0926669016302485>. Accessed: Mar. 13, 2020. doi: 10.1016/j. indcrop.2016.04.032.
TAIZ, L.; E. ZEIGER. Plant physiology. Porto Alegre: Artmed Editora. 2017. 719 p.

THAKUR, M.; R. KUMAR. Microclimatic buffering on medicinal and aromatic plants: A review. Industrial Crops and Products, v.160, p.113144. 2021. Available from: <https://www.sciencedirect. com/science/article/pii/S092666902031061X > . Accessed: Feb. 8, 2021. doi: 10.1016/j.indcrop.2020.113144

VAN BEEK, T. A.; D. JOULAIN. The essential oil of patchouli, Pogostemon cablin: A review. Flavour and Fragrance Journal, v.33, n.1, p.6-51. 2018. Available from: <https://doi.org/10.1002/ ffj.3418>. Accessed: Mar. 11, 2020. doi: 10.1002/ffj.3418.

YAO, X., et al. Effect of shade on leaf photosynthetic capacity, lightintercepting, electron transfer and energy distribution of soybeans. Plant Growth Regulation, v.83, n.3, p.409-416. 2017. Available from: <https://doi.org/10.1007/s10725-017-0307-y>. Accessed: Mar 21, 2020. doi: 10.1007/s10725-017-0307-y. 